\title{
Chlamydia trachomatis and Ureaplasma urealyticum in men attending a sexually transmitted diseases clinic
}

JENNIFER M HUNTER, * ISABEL W SMITH,† J F PEUTHERER, † A MACAULAY, $\uparrow \mathrm{S}$ TUACH, $\uparrow$ AND H YOUNG†

From the *Department of Genitourinary Medicine, Edinburgh Royal Infirmary, and the +Department of Bacteriology, University of Edinburgh, Edinburgh

SUMMARY Urethral specimens from 480 heterosexual patients were examined for Chlamydia trachomatis. Chlamydia were isolated from $32.7 \%$ of men with non-specific urethritis (NSU), from $16 \cdot 1 \%$ of men with gonorrhoea, and from $4 \cdot 1 \%$ of men without urethritis. Chlamydial isolation was not related to duration of symptoms, presence of discharge, or past history of attendance at the clinic.

Urine from 176 heterosexual patients was examined for Ureaplasma urealyticum. Ureaplasmas were present in $53.8 \%$ of men with NSU, in $28 \%$ of men with gonorrhoea, and in $32.9 \%$ of men with no urethritis. Detection rates for ureaplasmas in patients with chlamydia-negative and chlamydia-positive NSU were similar, but ureaplasmas were present in significantly greater numbers in patients with chlamydia-negative NSU than in those with chlamydia-positive NSU.

\section{Introduction}

Non-specific urethritis (NSU) is now the commonest sexually transmitted disease in the United Kingdom, ${ }^{12}$ but the aetiology in many cases is still obscure. The association of Chlamydia trachomatis with nongonococcal urethritis was first described by Dunlop et $a l^{3}$ in 1965 and the causal nature of this relationship now seems established, with $C$ trachomatis being isolated in $30-70 \%$ of cases. ${ }^{4-12}$

Ureaplasma urealyticum has also been implicated in the aetiology of nongonococcal urethritis and has been isolated from 40-60\% of patients with NSU. ${ }^{13-16}$ This association has been said to be particularly strong in chlamydia-negative NSU, ${ }^{17}$ but despite evidence from studies with antibiotics which differentiate between chlamydial NSU and ureaplasmal NSU ${ }^{18-20}$ and from the self-inoculation study reported by Taylor-Robinson et al, ${ }^{21}$ the aetiological role of ureaplasmas in NSU is still in doubt. ${ }^{16}$ The results of quantitative studies have also been conflicting. ${ }^{13} 1617$

The present study was performed to determine the prevalence of $C$ trachomatis and $U$ urealyticum infection in male patients attending a clinic for the

Address for reprints: Dr J M Hunter, Department of Genitourinary Medicine, Wards 45 and 46, Royal Infirmary, Edinburgh EH3 9YW

Accepted for publication 8 September 1980 treatment of sexually transmitted diseases. An attempt has also been made to evaluate the relationship between chlamydia and ureaplasmas in NSU.

\section{Patients and methods}

\section{STUDY POPULATION}

The study population was composed of $\mathbf{4 8 0}$ heterosexual male patients who attended the department of sexually transmitted diseases at the Edinburgh Royal Infirmary between October 1979 and January 1980. Those included were new patients and old patients returning with a fresh infection who presented between 9 am and 12 noon Monday to Friday and who had not received antibiotics during the six weeks preceding their initial visit.

\section{DIAGNOSTIC CRITERIA}

Gonorrhoea was diagnosed on the basis of positive urethral culture results for Neisseria gonorrhoeae with or without Gram-negative diplococci present on microscopy.

Non-specific urethritis was diagnosed irrespective of symptoms in patients in whom microscopical examination of Gram-stained urethral material or threads from the first specimen of urine showed 10 or more leucocytes per high power field $(\times 1000),{ }^{8}$ when gonorrhoea was excluded as above. 
Asymptomatic patients were those who complained of neither discharge nor dysuria and in whom there was no microscopical evidence of urethritis.

Patients with symptoms but without signs of urethritis were excluded from both of the last two diagnostic groups.

\section{ISOLATION PROCEDURES Gonorrhoea}

Samples for microscopy and culture were taken with plastic disposable bacteriological loops (Nunc Products). Specimens for culture were plated directly on to modified New York City medium.22 After incubation at $36^{\circ} \mathrm{C}$ for 24 hours $N$ gonorrhoeae was identified by rapid carbohydrate utilisation tests and delayed immunofluorescence or both. ${ }^{23}$

\section{Chlamydia trachomatis}

Specimens from the anterior urethra were taken using a sterile ENT swab (Medical Wire and Equipment Company) and placed in 2SP medium. They were stored at $-20^{\circ} \mathrm{C}$ for up to three hours and at $-60^{\circ} \mathrm{C}$ in the laboratory for up to three days before being cultured. Isolation was carried out by the method of Thomas et $a^{24}$ with cycloheximidetreated cells. Incubation of the infected cells was continued for three days at $35^{\circ} \mathrm{C}$ and the coverslips stained with iodine to detect the glycogen inclusions.

\section{Ureaplasma urealyticum}

The first-voided sample of urine, usually $7-10 \mathrm{ml}$, was collected in a sterile universal container. The sample was stored at room temperature for up to three hours before being transported to the laboratory and processed as described by Young et al. ${ }^{25}$ Results were expressed as the total number of colour-changing units (ccu) present in the initial urine sample. In the absence of any evidence to suggest otherwise, it was assumed that the total number of organisms present in the initial urine specimen was an accurate reflection of the numbers present in the anterior urethra.

\section{STATISTICAL ANALYSIS}

Statistical significance was determined by the $\chi^{2}$ test with Yates's correction or Student's $t$ test.

\section{Results}

CHLAMYDIA TRACHOMATIS

$C$ trachomatis isolation was attempted in 480 heterosexual men; the organism was isolated from 48 $(32.7 \%)$ of 147 men with NSU and from eight of 195 men with no evidence of urethritis (table I). This difference is highly significant $\left(\chi_{1}^{2}=48 \cdot 8 ; P<0 \cdot 001\right)$. Ten $(16 \cdot 1 \%)$ of the 62 men with gonorrhoea also harboured chlamydia.
TABLE I Chlamydia trachomatis in heterosexual men

\begin{tabular}{lrcrc}
\hline & & & \multicolumn{2}{c}{ Chlamydia-positive } \\
\cline { 4 - 5 } $\begin{array}{l}\text { Primary } \\
\text { diagnosis }\end{array}$ & No & $\begin{array}{c}\% \text { Of all } \\
\text { diagnoses }\end{array}$ & No & $\%$ \\
\hline Gonorrhoea & 62 & $12 \cdot 9$ & 10 & $16 \cdot 1$ \\
NSU & 147 & $30 \cdot 2$ & 48 & $32 \cdot 7$ \\
No symptoms & 195 & $40 \cdot 6$ & 8 & $4 \cdot 1$ \\
Other* & 76 & $16 \cdot 3$ & 11 & $14 \cdot 1$ \\
Total & 480 & $100 \cdot 0$ & 77 & $16 \cdot 0$ \\
\hline
\end{tabular}

*Patients with symptoms but without signs of urethritis at the time of initial examination.

The presence of a clinically detectable discharge and the duration of symptoms had no significant effect on the recovery of $C$ trachomatis. Indeed among the 21 patients with NSU who had no symptoms the organism was isolated from 10 $(47 \cdot 6 \%)$ patients.

C trachomatis was isolated from $10(35 \cdot 7 \%)$ of 28 patients with ureaplasma-positive NSU and from 10 $(41 \cdot 7 \%)$ of 24 patients with ureaplasma-negative NSU. This difference is not significant.

\section{CONTACT TRACING}

Although the study was not designed to include the contacts of the men examined, consorts of 14 of the 77 men infected with chlamydia were seen. Chlamydia were isolated from the seven cases tested.

\section{UREAPLASMA UREALYTICUM}

$U$ urealyticum was looked for in 176 heterosexual men; the organism was detected in $28(53 \cdot 8 \%)$ of 52 men with NSU but in only $32.9 \%$ of 73 asymptomatic men. This difference is significant $\left(\chi_{1}^{2}=4 \cdot 67\right.$; $0.02<\mathrm{P}<0.05)$. Ureaplasmas were present in 18 $(56 \cdot 3 \%)$ of 32 men with chlamydia-negative NSU and in $10(50 \%)$ of 20 men with chlamydia-positive NSU (table II). This difference is not significant $\left(\chi^{2}=0.02 ; \mathrm{P}>0.5\right)$.

Marked differences between chlamydia-negative and chlamydia-positive NSU occurred, however, when the number of ureaplasmas present was taken into account. Of patients with chlamydia-negative NSU $53 \cdot 1 \%$ had large numbers $\left(\geqslant 10^{5} \mathrm{ccu}\right)$ of ureaplasmas present in their urine compared with $15.0 \%$ of patients with chlamydia-positive NSU (table II). This difference is significant $\left(\chi_{1}^{2}=6 \cdot 03\right.$; $0.01<P<0.02$ ). The mean number of ureaplasmas present in men with chlamydia-negative NSU was $10^{7 \cdot 1}$ compared to $10^{4 \cdot 6}$ in men with chlamydiapositive NSU $(t=2 \cdot 13 ; \mathrm{P}<0 \cdot 05)$. The distribution of ureaplasmas in patients with chlamydia-positive and chlamydia-negative NSU is shown in the figure.

Although $U$ urealyticum was found less often in men with gonococcal urethritis and in men without urethritis (table II), it was usually present in large 
TABLE II Ureaplasma urealyticum in heterosexual men

\begin{tabular}{|c|c|c|c|c|c|c|c|}
\hline \multirow[b]{2}{*}{ Primary diagnosis } & \multirow[b]{2}{*}{ No } & \multicolumn{2}{|c|}{$\begin{array}{l}\text { Ureaplasma- } \\
\text { positive }\end{array}$} & \multicolumn{2}{|c|}{$\begin{array}{l}\text { With ureaplasmas } \\
\left(<10^{5} \text { ccu }\right)\end{array}$} & \multicolumn{2}{|c|}{$\begin{array}{l}\text { With ureaplasmas } \\
\geqslant 10^{5} \text { ccu) }\end{array}$} \\
\hline & & No & $\%$ & No & $\%$ & No & $\%$ \\
\hline $\begin{array}{l}\text { Gonorrhoea } \\
\text { Chlamydia-negative NSU } \\
\text { Chlamydia-positive NSU } \\
\text { No symptoms }\end{array}$ & $\begin{array}{l}25 \\
32 \\
20 \\
73\end{array}$ & $\begin{array}{r}7 \\
18 \\
10 \\
24\end{array}$ & $\begin{array}{l}28 \cdot 0 \\
56 \cdot 3 \\
50 \cdot 0 \\
32 \cdot 9\end{array}$ & $\begin{array}{l}2 \\
1 \\
7 \\
8\end{array}$ & $\begin{array}{r}8 \cdot 0 \\
3 \cdot 1 \\
35 \cdot 0 \\
11 \cdot 0\end{array}$ & $\begin{array}{r}5 \\
17 \\
3 \\
16\end{array}$ & $\begin{array}{l}20 \cdot 0 \\
53 \cdot 1 \\
15 \cdot 0 \\
21 \cdot 9\end{array}$ \\
\hline
\end{tabular}

$\mathrm{ccu}=$ colour-changing $\mathrm{units}$

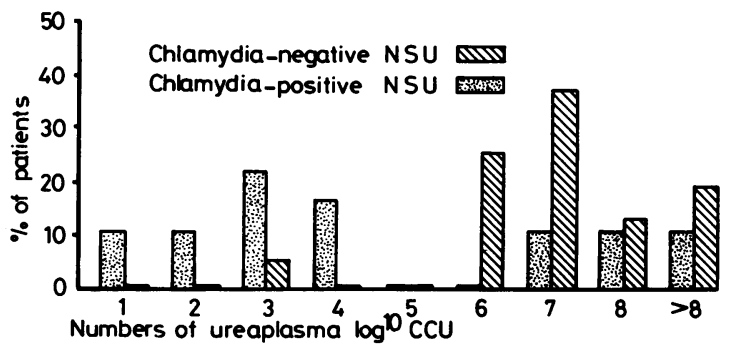

FIGURE Number of ureaplasmas in patients with NSU

numbers. Ureaplasmas were present in numbers equal to or greater than $10^{5} \mathrm{ccu}$ in five of the men with gonococcal urethritis who harboured ureaplasmas and in 16 of the men without urethritis.

\section{Discussion}

Any consideration of non-specific urethritis is complicated by the lack of universally accepted criteria for its diagnosis; even within England and Wales $^{26}$ there are marked variations in the criteria applied. This may partly account for the differences in reported isolation rates for $C$ trachomatis, which range from $26 \%{ }^{10}$ to $58 \cdot 5 \%{ }^{11}$ in recent surveys; there is a tendency for the highest isolation rates to be reported by those authors who restrict their diagnosis of urethritis to patients whose urethral exudates contain more than 20 leucocytes per high power field on microscopical examinations. The isolation rate of $33 \%$ for $C$ trachomatis in NSU in the study reported here is similar to that obtained by others using the same diagnostic criteria. ${ }^{810}$

Unlike other authors ${ }^{78}$ we were unable to relate isolation of $C$ trachomatis to either severity or duration of symptoms, and we obtained particularly high isolation rates in patients with NSU who had no symptoms.

The significance of $U$ urealyticum in NSU is much less well established. The overall isolation rate of $53 \cdot 8 \%$ reported here agrees with the $52 \cdot 9 \%$ reported by Taylor-Robinson et al, ${ }^{16}$ but he found no significant difference between chlamydia-positive and chlamydia-negative NSU in terms of the numbers of organisms present. However, the results of quantitative studies have been conflicting, and Hare et al ${ }^{13}$ detected "high numbers" of ureaplasmas in chlamydia-negative NSU more frequently than in chlamydia-positive NSU.

In the present study we found that $U$ urealyticum could be detected fairly frequently in sexually active men, and large numbers $\left(\geqslant 10^{5} \mathrm{ccu}\right)$ could be present without causing any evidence of urethritis. Nevertheless, the organism is isolated more often from men with NSU, and a causative role for $U$ urealyticum in some cases cannot be excluded. The factors which might influence the pathogenicity of the organism are not known, but the observation that ureaplasmas were found in low numbers in chlamydia-positive NSU might indicate some inhibitory action of $C$ trachomatis. It seems unlikely that detection of the organism is influenced by the presence of urethritis, as detection rates and numbers of the organisms present are similar for patients with gonococcal urethritis and those without urethritis.

This study provides further support for the aetiological role of $C$ trachomatis in NSU, but the case for such a role for $U$ urealyticum is still not proved.

We are grateful to our medical and non-medical colleagues in the University Department of Genitourinary Medicine, Edinburgh Royal Infirmary, for their help in the collection of specimens and data and in the preparation of this paper.

\section{References}

1. Scottish Home and Health Department. Scottish Health Statistics, Edinburgh: HMSO 1978.

2. Department of Health and Social Security. Extract from the Annual Report of the Chief Medical Officer for the year 1977. Br J Vener Dis 1979; 55:225-9.

3. Dunlop EMC, Al Hussain MK, Garland JA, Treharne JD, Harper IA, Jones BR. Infection of the urethra by TRIC agent in men presenting because of non-specific urethritis. Lancet 1965; i: $1125-8$. 
4. Dunlop EMC, Vaughan Jackson JD, Darougar S, Jones BR. Chlamydial infection: incidence in non-specific urethritis. $\mathrm{Br} \mathbf{J}$ Vener Dis 1972; 48:425-8.

5. Oriel JD, Reeve $\mathbf{P}$, Davis $\mathbf{P}$, Miller $\mathbf{A}$, Nicol CS. Isolation of chlamydia from patients with non-specific genital infection. $\mathrm{Br}$ $J$ Vener Dis 1972;48:429-36.

6. Holmes KK, Handsfield $\mathrm{HH}$, Wang SP, et al. Etiology of non gonococcal urethritis. New Engl J Med 1975;292:1199-205.

7. Oriel JD, Reeve P, Wright JT, Owen J. Chlamydial infection of the male urethra. Br J Vener Dis 1976;52:46-51.

8. Alani MD, Darougar S, Burns DCM, Thin RN, Dunn H. Isolation of Chlamydia trachomatis from the male urethra. $\mathrm{Br} J$ Vener Dis 1977; 53:88-92

9. Perroud HM, Miedzybrodzka K, Chlamydial infection of the urethra in man. Br J Vener Dis 1978; 54:45-9.

10. Ripa KT, Mårdh DA, Thelin I. Chlamydia trachomatis urethritis in men attending a venereal disease clinic. Acta Dermatovenereol (Stockholm) 1978; 58: 175-9.

11. Terho P. Chlamydia trachomatis in non-specific urethritis. $\mathrm{Br}$ $J$ Vener Dis 1978;54:251-6.

12. Ghadirian FD, Robson HG. Chlamydia trachomatis genital infections. Br J Vener Dis 1979;55:415-8.

13. Hare MJ, Dunlop EMC, Taylor-Robinson D. Mycoplasmas and non-specific genital infections. Br J Vener Dis 1969;45: 282-6.

14. Paavonen J, Kousa M, Saikku P, Vesterinen E, Jansson E, Lassus A. Examination of men with non-gonococcal urethritis and their sexual partners for Chlamydia trachomatis and Ureaplasma urealyticum. Sex Transm Dis 1978;5:93-6.

15. Bowie WR, Alexander ER, Holmes KK. Etiologies of postgonococcal urethritis in homosexual and heterosexual men. Sex Transm Dis 1978; 5: 151-4.

16. Taylor-Robinson D, Evans RT, Coufalik ED, et al. Ureaplasma urealyticum and Mycoplasma hominis in chlamydial and non-chlamydial post-gonococcal urethritis. $\mathrm{Br}$ $J$ Vener Dis 1979;55:30-5.

17. Bowie WR, Wang SP, Alexander ER, Holmes KK. Etiology of non-gonococcal urethritis. In: Hobson D, Holmes KK, eds. Non-gonococcal Urethritis and Related Infections. Washington DC: American Society for Microbiology, 1977; 19-29.
18. Prentice MJ, Taylor-Robinson D, Csonka GW. Non-specific urethritis. A placebo controlled trial of minocycline in conjunction with laboratory investigations. $\mathrm{Br} J$ Vener Dis 1976;52:269-75.

19. Bowie WR, Alexander ER, Floyd JF, Holmes J, Miller Y, Holmes KK. Differential response of chlamydial and ureaplasma-associated urethritis to sulphafurazole (sulfisoxazole) and aminocyclitols. Lancet 1976; ii: 1276-8.

20. Coufalik ED, Taylor-Robinson D, Csonka GW. Treatment of non-gonococcal urethritis with rifampicin as a means of defining the role of Ureaplasma urealyticum. Br J Vener Dis 1979; 55:36-43.

21. Taylor-Robinson D, Csonka GW, Prentice MJ. Human intraurethral inoculation of ureaplasmas. Quart J Med 1977;46: 309-26.

22. Young $\mathrm{H}$. Cultural diagnosis of gonorrhoea with modified New York City (MNYC) Medium. Br J Vener Dis 1978;54: 36-40.

23. Young H, Paterson IC, McDonald DR. Rapid carbohydrate utilisation test for the identification of Neisseria gonorrhoeae. Br J Vener Dis 1976; 52: 172-5.

24. Thomas BJ, Evans RT, Hutchison GR, Taylor-Robinson D. Early detection of chlamydial inclusions combining the use of cycloheximide-treated McCoy cells and immunofluorescence staining. J Clin Microbiol 1977;6:285-92.

25. Young H, Tuach S, and Bain SSR. Incidence of Ureaplasma urealyticum infection in women attending a clinic for sexually transmissible disease. $J$ Infect 1981 (in press).

26. Adler MW. Diagnostic treatment and reporting criteria for non-specific genital infection in sexually transmitted disease clinics in England and Wales. I Diagnosis. Br J Vener Dis 1978; 54:422-7. 